
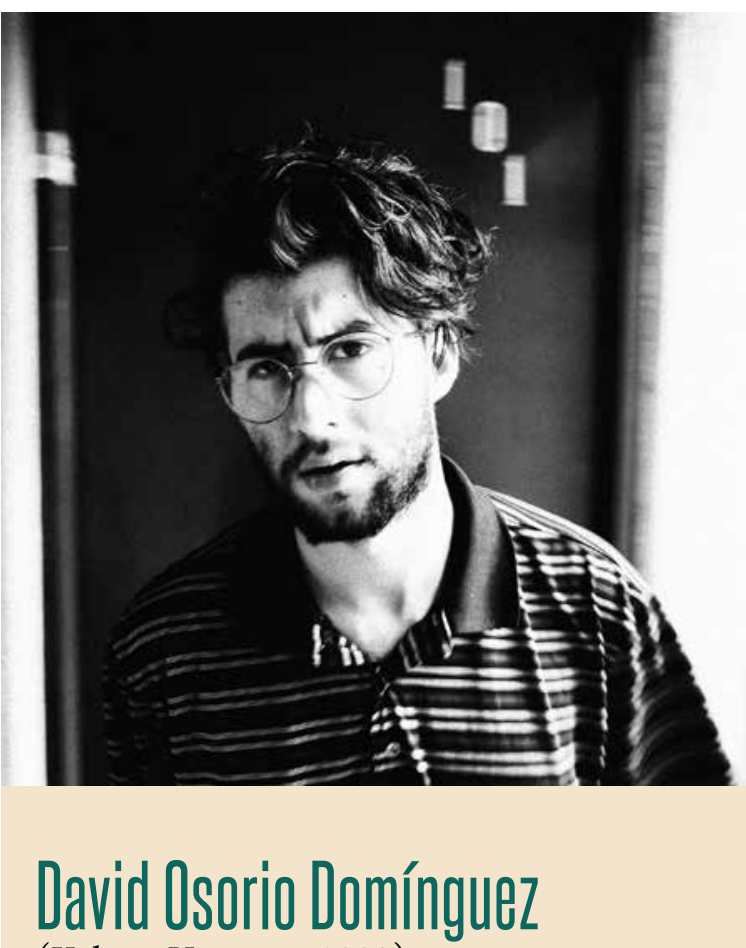

(Xalapa, Veracruz, 1993)

Se ha dedicado de manera autodidacta a la fotografía, mostrando un interés especial por la street photography. Desde 2013 su trabajo se ha enfocado en la producción audiovisual, por lo que ha colaborado con diversas empresas publicitarias en países como Venezuela, Bolivia, Ecuador, España y México.

En este número de La Palabra presentamos el documental fotográfico que realizó centrándose en un personaje de las calles de Xalapa: Olle Hedman, también conocido como Olov u Olovs$k y$, a quien, en tanto protagonista del reportaje, introducimos con el siguiente texto de María Teresa G. LPyH

\section{Olle Hedman: perro fluorescente}

Olle Hedman nace en Estocolmo, Suecia, en 1940, país donde pasa la mayor parte de su vida; primero estudiando publicidad en la Universidad de Bergh, luego como alumno del cineasta Claes Söderquist y, finalmente, como conductor de un taxi los fines de semana.
Cambió su labor de publicista por la de cineasta, y desde ella apostó por una estética surrealista y experimental. Plasmó su particular visión cinematográfica en formato súper 8, pasando por el film en blanco y negro, hasta la sola presencia de diálogos sobre un fondo neutro. Es decir, creó un juego audiovisual lleno de movimientos y luces poco comunes en el cine comercial. Destacan en este sentido filmes como Oremus (1976), Phantom Conception (1978), Instant Movie (1979) y Metro: Means of Conveyance (1977).

Después de una abundante producción y de lograr el reconocimiento de la crítica sueca e internacional (a finales de 1970 era de los pocos cineastas experimentales activos), Hedman decide abandonar su círculo de artistas, su vida y su nación. Al azar, realiza un viaje a México, particularmente a la ciudad de Xalapa, cansado de no encontrar una respuesta en el cine. Todo lo que debía hacer estaba hecho. Y se mantuvo firme en sus ideales respecto a lo que el arte debe ser: libertad.

Hedman se convierte, así, en un personaje más de Xalapa, un hombre que pasa desapercibido en las calles y que deambula por el centro de la ciudad al mismo tiempo que por un mundo fantástico dentro de su cabeza. Comienza a escribir poesía en español, lengua desconocida hasta entonces para él:

"La ausencia / se expande a lo irreal / repentinamente claridad / después oscuridad en la metrópoli / poblado de perros fluorescentes / que olfatean a cada transeúnte."

En este viaje por la urbe, coincide con David Osorio. Inmediatamente hay una conexión y un reconocimiento en el otro: ambos son perros fluorescentes y transeúntes. Después de intercambiar anécdotas y entablar una amistad, Osorio se interesa por establecer un diálogo con Hedman en el lenguaje que mejor conoce: el de la fotografía. Le interesa mostrar a este hombre sombrío y reservado, el misterio de su estilo de vida, lo oculto en su cotidianidad.

Es así como surge este documental fotográfico que retrata, sirviéndose de elementos del universo artístico de David Osorio, el mundo fragmentado de Olle Hedman. Estamos frente a una atmósfera muy al estilo Chris Marker: una captura del movimiento y el vértigo de un personaje observado desde cerca y desde distintos ángulos; un blanco y negro impecable que nos lleva directamente a los gestos del protagonista de la fotografía. LPyH 